\author{
${ }^{1}$ Department of Evolutionary Zoology \& Human Biology, Institute of Biology \& Ecology, University of Debrecen, Debrecen; \\ ${ }^{2}$ MTA-DE 'Lendület' Behavioural Ecology Research Group, Budapest; ${ }^{3}$ Research Institute for Viticulture and Oenology, Tarcal; \\ ${ }^{4}$ MTA-ELTE-MTM Ecology Research Group, Budapest Hungary
}

\title{
Multilevel studies on the two phenological forms of Large Blue (Maculinea arion) (Lepidoptera: Lycaenidae)
}

\author{
Judit Bereczki ${ }^{1,2}$, János P. Tóth ${ }^{1,3}$, Gábor Sramkó $^{4}$ and Zoltán Varga ${ }^{1}$
}

\begin{abstract}
The main goal of our research was to study comprehensively the differences between the two phenological forms of the socially parasitic and globally threatened Large Blue (Maculinea arion) in the Carpathian Basin using four character sets (mitochondrial sequences, allozymes, male genitalia and wing morphometrics). Comparative analyses of distance matrices, phylogenetic trees and ordination patterns have been applied. The genetic and morphometric patterns revealed by our studies were discordant. While we experienced a significant differentiation between the 'spring' and 'summer type' of $M$. arion in both wing and genital traits, the two phenological forms did not show any genetic differentiation on two mitochondrial loci and in allozymes. At the same time, all individuals were infected by Wolbachia. Although certain wing traits may not represent reliable tracers of phylogeny because of the particular adaptive significance, the wing characteristics involved in our research are probably determined genetically. Additionally, the significant differentiation of male genitalia also indicates incipient prezygotic isolation arising from phenological differentiation between the 'spring and summer arion'. It is possible that all extant differences between the two forms are attributable to (1) different host-ant use, (2) incipient speciation, (3) cytoplasmatic incompatibility (CI) by Wolbachia or the combination of these factors. In addition, discordant results indicate that the combined use of different approaches and data sets is strictly necessary to clarify systematic and evolutionary relationships.
\end{abstract}

Key words: Spring and summer arion - mtDNA variability - Wolbachia - geometric morphometry - Carpathian Basin

\section{Introduction}

In the past few decades, traditional morphology-based taxonomy has been increasingly replaced by DNA-based species identification. A short, standardized gene region of mtDNA (mitochondrial cytochrome c oxidase subunit I - COI) was proposed as a 'DNA barcode' for discriminating most animal species (Hebert et al. 2003; Dinca et al. 2010). The proposal to develop an identification system based on a single gene marker attracted early criticism (Ebach and Holdrege 2005). Additionally, performance tests have shown significant differences in identification success in the case of different animal groups (Hebert et al. 2004; Wiemers and Fiedler 2007). As a consequence, a great need remains for comprehensive studies and in-depth multidisciplinary assessments before any conclusion is drawn. Such a multilevel approach became necessary to study the distinctness of two phenological forms of the Large Blue (Maculinea arion).

The genus Maculinea Van Eecke, $1915^{1}$ (Lepidoptera: Lycaenidae) is one of the most intensively studied insect groups in Europe (Settele et al. 2005). This is partly attributable to their very special social parasitic life cycle and partly to being umbrella species (Fleishman et al. 2005; Spitzer et al. 2009). Additionally, these butterflies face a serious conservation risk as their habitats have suffered severe decrease and fragmentation. Within the genus Maculinea, one of the most conspicuous declines was shown by the Large Blue - Maculinea arion (Linnaeus, 1758). This species became extinct in the Netherlands in 1964 (Tax 1989), in the UK in 1979 (Thomas 1995) and in Belgium in 1996 (although later the species was re-introduced

Corresponding author: Judit Bereczki (bereczki.judit@gmail.com) Contributing authors: János P. Tóth (acutiformis@yahoo.com), Gábor Sramkó (sramko.gabor@science.unideb.hu), Zoltán Varga (zvarga@tigris. unideb.hu)

${ }^{1}$ Here, we follow the recommendation of Balletto et al. (2010) concerning the generic names Maculinea Van Eecke, 1915 versus Phengaris Doherty, 1891 . into the UK and it also re-colonized in Belgium) (Goffart 1997). It shows a serious retreat all over Europe, especially on the northern border of the distribution area of the species (Wynhoff 1998); therefore, Large Blues are endangered on a European scale. The species is included in Annex IV of the European Habitats' Directive, and it is listed in the IUCN Red List of Threatened Species as 'near threatened' and considered as 'endangered' (EN) in the European Red List of Butterflies (Munguira and Martin 1997; Van Swaay et al. 1998, 2010).

Maculinea arion is a highly variable species morphologically. Nowadays there are at least twenty named forms listed (Verity 1940-1953; Cheshire 2011) and three subspecies are commonly recognized in Europe (Higgins and Riley 1970; Thomas 1996; Tolman and Lewington 2009): (1) Maculinea arion arion (Linnaeus, 1758) is the most widespread nominate form, which is described from Germany (Nürnberg); (2) Maculinea arion ligurica (Wagner, 1904), which is described from Liguria region of north-western Italy originally as a varietas; (3) Maculinea arion obscura (Christ, 1878) is a high-mountain form in the Swiss Central Alps (Zermatt, Liestal), but phenotypically similar forms also occur in high mountains of the Balkan Peninsula. In the Carpathian Basin, the former two subspecies have been reported (Varga 2010), and there are numerous differences between them. The fast-flying, smaller-sized and dark violet-blue $M$. a. arion (referred to as 'spring arion' hereafter) flies from mid-May to mid-June and prefers short-grass dry swards with cushions of early-flowering Thymus species (Th. serpyllum L., Th. pannonicus All. and related species), which serve as initial food plants. The slower, larger and light silvery blue M. a. ligurica (referred to as 'summer arion') is on the wing from the end of June to mid-August and mostly occurs at xerothermic oak forest fringes, on woodland clearings and in fen-like habitats in hilly areas. Females oviposit among flower buds of late-flowering Thymus species (mostly Th. pulegioides L.) and/or Origanum vulgare L. (Varga 2010; : Annotation No. R23). Although differences in food plant use also imply some difference in habitat preference, there is only a weak ecological isolation between the two forms.

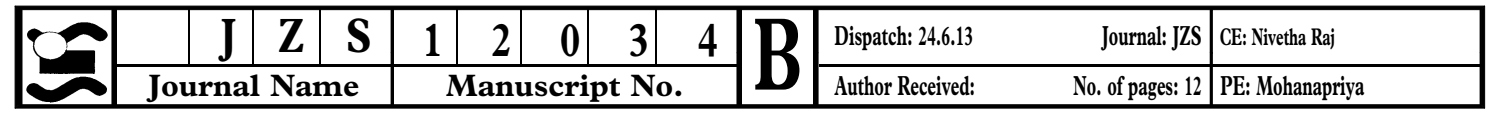


Moreover, numerous syntopic occurrences of the 'spring' and 'summer arion' have been recorded in Aggtelek Karst region (Hungary) (Tóth \& Bereczki, pers. obs.). Our knowledge on the host-ant use of the two subspecies is insufficient. Myrmica sabuleti Meinert, 1861 is known to be the main host ant of M. arion in Western Europe, and it was also found as a putative host ant in some M. arion habitats in Hungary (Tartally 2008). In Poland, $M$. arion is characterized by multiple host-ant use, which varies geographically (Sielezniew et al. 2003, 2010a,b,c; Sielezniew and Stankiewicz 2008). Hitherto, ant-nests infected by larvae of $M$. arion have not been found in Hungary probably because of the lack of intensive surveys. The phylogenetic studies focusing on the section Glaucopsyche show potential cryptic species within the predatory Maculinea, and high divergences were also found in M. arion (Als et al. 2004; Fric et al. 2007; Ugelvig et al. 2011b). Consequently, the two phenological forms of M. arion may be candidates for putative cryptic species.

2 At the same time, Sielezniew (2012) and Sielezniew et al. (2012) discovered Wolbachia infestation in M. arion and $M$. alcon populations, which may have influence on phylogeny of Maculinea species. Wolbachia infections are associated with a variety of phenotypic effects on the hosts: (1) cytoplasmatic incompatibility (CI); (2) male killing, the consequence of which is sex ratio distortion; (3) feminization of genetic males, which may also bias the sex ratio; and (4) parthenogenesis induction. The former three effects have been revealed in butterflies. CI, that is, when the sperm of infected males is incapable of fertilizing the eggs of uninfected females and females infected with a different Wolbachia strain, is the most frequently observed phenotype (Hoffmann and Turelli 1997; Werren et al. 2008). The spread of Wolbachia via CI can drive the spread of maternally inherited genetic elements, such as mtDNA. Specific mitochondrial genotypes may be associated with a Wolbachia CI strain surreptitiously. Consequently, the distribution of mtDNA variation in infected populations does not conform to the expectations of neutral theory (Narita et al. 2007; Gompert et al. 2008; Nice et al. 2009), which has been revealed not only in butterflies, but also in other invertebrate species (Turelli and Hoffmann 1991; Shoemaker et al. 2003; Shaikevich et al. 2005). Wolbachia may homogenize biological species for mtDNA following introgression of endoparasites, as reported in Acrea (Jiggins 2003) and
Drosophila (Ballard and William 2000b), causing a 'one barcode - two species' phenomenon (i.e. two biological entities have the same mtDNA sequence). On the contrary, Wolbachia can make one species appear as two due to the high intraspecific mtDNA diversity associated with possession of different parasite strains, as reported in Adalia (Hurst et al. 1999a,b), leading to a 'two barcodes - one species' phenomenon. Additionally, divergent mitochondrial sequences may suggest the presence of cryptic species falsely (Hurst and Jiggins 2005).

Although our previous results (Bereczki et al. 2011) have $\mathbf{3}$ shown that the two putative subspecies cannot be differentiated based on allozyme loci, we intended to study the dissimilarities between the two forms in a multilevel research including DNA and morphological surveys. We also intended to explore whether the outcome of the different methods would be congruent or not. Besides, we were interested in discovering whether the influence 4 of Wolbachia on mtDNA variability and selective sweep works in $M$. arion populations. Thus, the aims of our research were: (1) to reveal whether the two types of $M$. arion differentiate on the basis of mitochondrial sequences, (2) to establish the measure of the differentiation in allozymes, (3) to study the morphological differences between them on the traits of external genitalia and wings and (4) to compare the level of the genetic and morphometric differentiation.

\section{Materials and methods}

\section{Sampling}

DNA studies were based on sequences of 29 field-collected specimens (Appendix 1, Fig. 1), of which nine were 'spring arion' and 15 were 'summer arion' (the identification was carried out based on the date of sampling). We had four couples of 'spring and summer arion' from the same locality (see in boldface in Appendix 1, Fig. 1). We used only one M. arion individual from GenBank database (identifier: SPAus - accession number: HQ918148.1) because only its sequence overlapped completely with those of our samples. Maculinea alcon, M. teleius and M. nausithous specimens were used as outgroups.

In our allozyme and morphometric studies, we used the same set of individuals (only males). Altogether 11 samples (143 individuals) were collected between 2002 and 2011 (Appendix 2, Fig. 1): four were 'spring type' and seven were 'summer type' $M$. arion (the identification was also

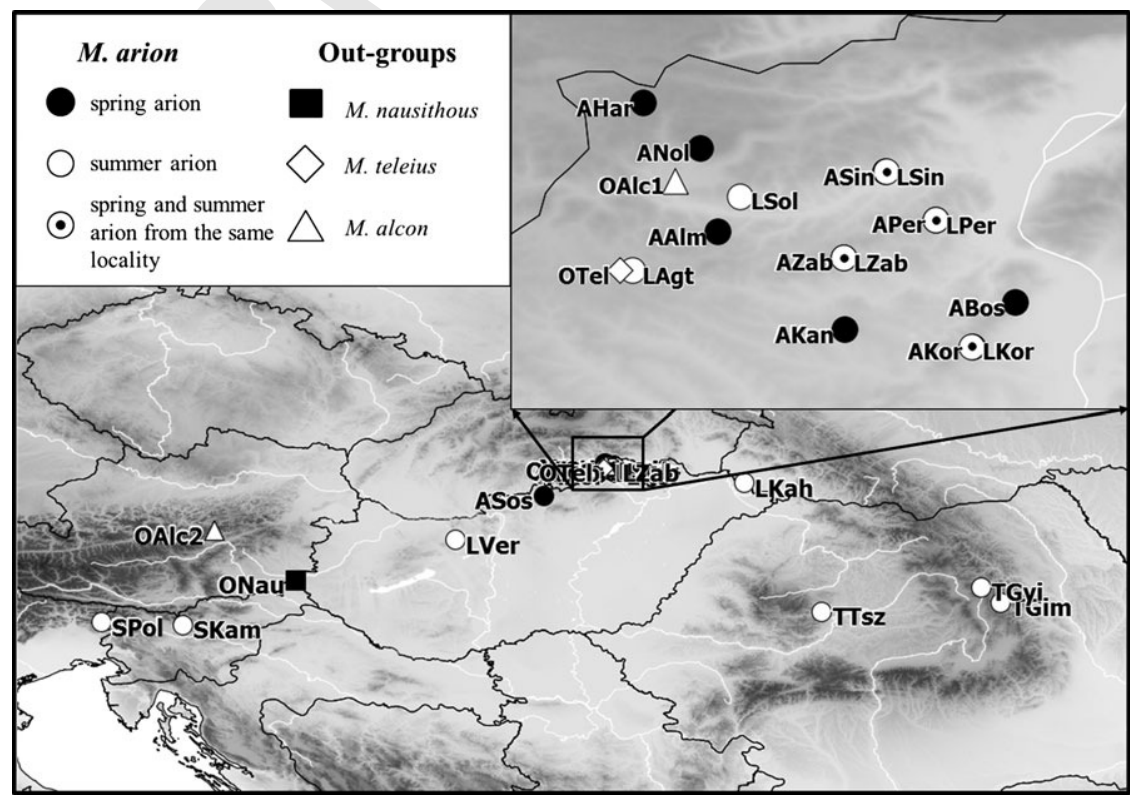

Fig. 1. Sample sites. See the abbreviations in Appendices 1 and 2 
carried out based on the sampling time). We possessed one pair of samples originated from the same syntopic population (see in boldface in Appendix 2). The samples from Kamnik and Polovnik (Slovenia) were unified because of the low number of individuals. M. nausithous (16 individuals) was included as outgroup. Images were collected at the end of the egg laying period and stored at $-80^{\circ} \mathrm{C}$ until electrophoresis and morphometric analyses.

\section{Molecular analyses}

\section{DNA studies}

DNA was extracted by homogenizing either the head or thorax (Appendix 1) in $800 \mu \mathrm{l}$ extraction buffer (Gilbert et al. 2007). The samples were incubated for $24 \mathrm{~h}$ at $56^{\circ} \mathrm{C}$ with gentle agitation and then centrifuged at

5 $14000 \mathrm{rpm}$ for $1 \mathrm{~min}$. The supernatant was washed twice with an equal volume of chloroform-isoamyl alcohol $(24: 1)$ to remove proteins. The DNA was precipitated by adding the mixture of $80 \mu \mathrm{l}$ ammonium acetate $(7.5 \mathrm{M})$ and an equal volume of ice-cold isopropanol and storing the samples at $-20^{\circ} \mathrm{C}$ for $4 \mathrm{~h}$. The DNA was pelleted by centrifugation a $14000 \mathrm{rpm}$ for $10 \mathrm{~min}$ at $4^{\circ} \mathrm{C}$. After centrifugation, the supernatant was discarded and the DNA pellet was washed twice with $70 \%$ ice-cold ethanol. The pellet was air-dried for $1 \mathrm{~h}$ at room temperature and was redissolved in $50 \mu$ l elution buffer $(10 \mathrm{mM}$ Tris- $\mathrm{HCl}, \mathrm{pH} 8.0$ and $0.5 \mathrm{mM}$ EDTA, pH 9.0). DNA aliquots were stored at $4^{\circ} \mathrm{C}$.

The I subunit of the cytochrome c oxidase gene (COI), which is commonly used in barcoding animal life (Hebert et al. 2003; Wiemers and Fiedler 2007), offers an adequate tool to test whether the morphological and ecological differences between the two forms of $M$. arion manifest at the DNA level. We therefore sequenced this section of the mitochondrial genome together with subunit II (COII) to obtain insight into the phylogeny of taxa at the species level. These two mitochondrial genes were amplified by four modified universal primer pairs (COI: HybLCO and HybHCO, HybJerry and HybPat of Wahlberg and Wheat (2008); COII: Georges and Phyllis, Strom and BtLys of Monteiro and Pierce (2001)). Primers were modified at their $5^{\prime}$-end to include the universal sequencing primer T4 promoter. Amplification from $1 \mu \mathrm{l}$ of DNA extracts was carried out in $25 \mu \mathrm{l}$ final reaction volumes containing $10 \times$ PCR buffer, $2 \mathrm{mM} \mathrm{MgCl} 2,0.2 \mathrm{mM}$ dNTPs, 0.02 units per $\mu \mathrm{l}$ of Taq DNA polymerase (Dream Taq Green, Fermentas) and $0.2 \mu \mathrm{M}$ of each primer. Amplification was carried out in an ABI Veriti thermal cycler programmed for initial denaturation for $3 \mathrm{~min}$ at $94^{\circ} \mathrm{C} ; 35$ cycles of $30 \mathrm{~s}$ at $94^{\circ} \mathrm{C}, 30 \mathrm{~s}$ a the locus-specific annealing temperature of $54 / 54 / 52 / 56^{\circ} \mathrm{C}$ (in the order of primer pairs, see above), $1 \mathrm{~min}$ at $72^{\circ} \mathrm{C}$; final elongation of $10 \mathrm{~min}$ at $72^{\circ} \mathrm{C}$. The success of PCR amplification was checked by running $2 \mu \mathrm{o}$ product on $1 \%$ agarose gels stained with ethidium bromide. PCR products were sequenced by commercial service provider Macrogen Inc.

6 (South Korea). Sequences were edited and revised manually by CHROMAS 7 LITE v. 2.01 and aligned by MEGA v. 4.0 (Tamura et al. 2007).

The presence of Wolbachia was checked by the amplification of the 16S ribosomal region with Wolbachia-specific primers W-Spec of Werren and Windsor (2000) following their guidelines of amplification. Infected accessions (Appendix 1) were tested further with the strain-specific ftsZ primers and PCR conditions of Werren et al. (1995) and Sasaki et al. (2002).

Based on the concatenated COI and COII sequences, phylogenetic tree reconstruction methods of three different search criteria were applied to demonstrate phylogenetic relationship between the 'spring' and 'summer arion'. Heuristic searches were run in PAUP v. 4.0b10* (Swofford 2003) under both maximum parsimony (MP) and maximum-likelihood (ML) criterion separately, while Bayesian phylogenetic relationships were

8 assessed in MRBAYES v. 3.2.1 (Ronquist et al. 2012). The MP search used TBR search algorithm holding 10 trees at each iteration step with 'MulTree' option in effect, while 'steepest descent' not in effect. The ML search utilized an evolutionary model of TVM+I as selected by MODEL TEST v. 3.7 (Posada and Crandall 1998) with default settings. For the Bayesian analysis, we specified the evolutionary model $\mathrm{HKY}+\mathrm{I}+\mathrm{G}$ as selected by mRMODELTEST v. 2.3 (Nylander 2004), and two separate runs were conducted for 2 million generation samplings every 1000th generation. Resulting probability files were checked by TRACER V. 1.5 (Drummond and Rambaut 2007) for convergence and effective sample sizes of the runs, then were combined and a maximum clade credibility tree was computed after discarding first $25 \%$ of trees as 'burn-in'. Al analyses were run on Bioportal (Kumar et al. 2009).

\section{Allozyme studies}

Allozyme polymorphism was studied at 12 loci by vertical polyacrylamide gel electrophoresis. Thoraxes homogenized in $300 \mu \mathrm{l}$ of extraction buffer were used to study Gpdh, G6pgdh, Hk,Idh, Mdh, Pgi, Pgm and Sod. Abdomens homogenized in $200 \mu \mathrm{l}$ of extraction buffer were used to analyse Acon, Acph, Aox and Est. The extraction buffer, the electrophoresis buffer systems and running conditions, together with the staining solutions, were applied as described in Bereczki et al. (2005). Genotypes of the individuals were scored according to their enzyme pattern.

Since our previous research (Bereczki et al. 2011) has involved a detailed study about the allozyme variability of $M$. arion, the recent study has been based on a reduced data set. Therefore, this paper only includes the analyses that have been carried out in parallel with the morphometric surveys. Allele frequencies were used to estimate Nei's genetic distances (Nei 1975), and an UPGMA dendrogram (Sneath and Sokal 1973) was constructed on the basis of the distance matrix using Past v. 2.17 (Hammer et al. 2001). Pairwise $\mathrm{F}_{\mathrm{ST}}$ values were also established by GENALEX v. 6.4 (Peakall and Smouse 2006).

\section{Morphometric analyses}

Prior to electrophoresis, wings and the terminal segments of the abdomen were cut. Wings were fixed on transparency films and photographed by Sony DSC-H2 digital camera. Landmark-based geometric morphometric approach was used to quantify the variation in the shape of wings and the pattern of black spots on the underside. We recorded 17 landmarks on fore-wing and 16 on hind-wing (only one side was measured in both cases) by TPSDIG v. 2.1 (Fig. 2a). Procrustes generalized least squares 9 (GLS) method was applied to get the superimposed coordinates for the statistical analyses.

The preparation procedure of male external genitalia was slightly modified after Robinson (1976). The sclerotized genitalia were separated from the body tissues by keeping the terminal segments of the abdomen in $15 \% \mathrm{KOH}$ overnight, followed by heating for $30 \mathrm{~min}$ at $75^{\circ} \mathrm{C}$ before preparation. The genitalia were cleaned and dehydrated with $96 \%$ ethanol and mounted in Euparal fixative (mounting medium) on microscope glass. Slides were digitalized by combining an Olympus camera and a Nikon 102 stereomicroscope. Since we found only few real landmarks on valvae, we recorded a close curve on them using TPSDIG v. 2.1 (Fig. 3a). For the analysis of the outlines, elliptic Fourier analysis (Giardina and Kuhl 1977; Kuhl and Giardina 1982) was used. The algorithm fits Fourier series on $\mathrm{x}$ - and $\mathrm{y}$-coordinates as functions of the curvilinear abscissa (Claude 2008). The statistical analyses of the two morphometric approaches were similar.

Repeatability was calculated by the following formula: ME $=S_{\text {within }}^{2} /\left(S_{\text {within }}^{2}+S_{\text {among }}^{2}\right) \times 100$ (Lessells and Boag 1987), where $S_{\text {within }}^{2}$ is the within-measurement component of variance and $S_{\text {among }}^{2}$ is the among-measurement component. ANOVA was used to calculate these values (Bailey and Byrnes 1990; Yezerinac et al. 1992) in R programme package (R Development Core Team 2010). Principal component analyses (PCAs) were applied to reduce the number of variables. The scores of the PC axes that could explain more than $1 \%$ of the total variance were used in canonical variates analysis (CVA) and multivariate analysis of variance (MANova) (see: Dapporto et al. 2009, 2011; Dinca et al. 2011). Jack-knifed grouping and Wilks' lambda were applied to quantify the validity of the visible pattern.

UPGMA tree was constructed based on Mahalanobis distances. The differences in centroid sizes (the square root of the summed squared distances of each landmark from the centre of the form) were analysed by univariate ANOVA. All morphometric analyses were carried out using PAST 2.17 (Hammer et al. 2001).

\section{Results}

\section{Molecular studies}

Four bits of mitochondrial $(\mathrm{mt})$ cytochrome c sequences were concatenated into one 'contig' sequence for all studied taxa containing full mtCOI and partial mtCOII sequences. Final concatenated sequences were aligned without the need of introducing gaps into a matrix of 2217 base pairs (bp), of which $1361 \mathrm{bp}$ 


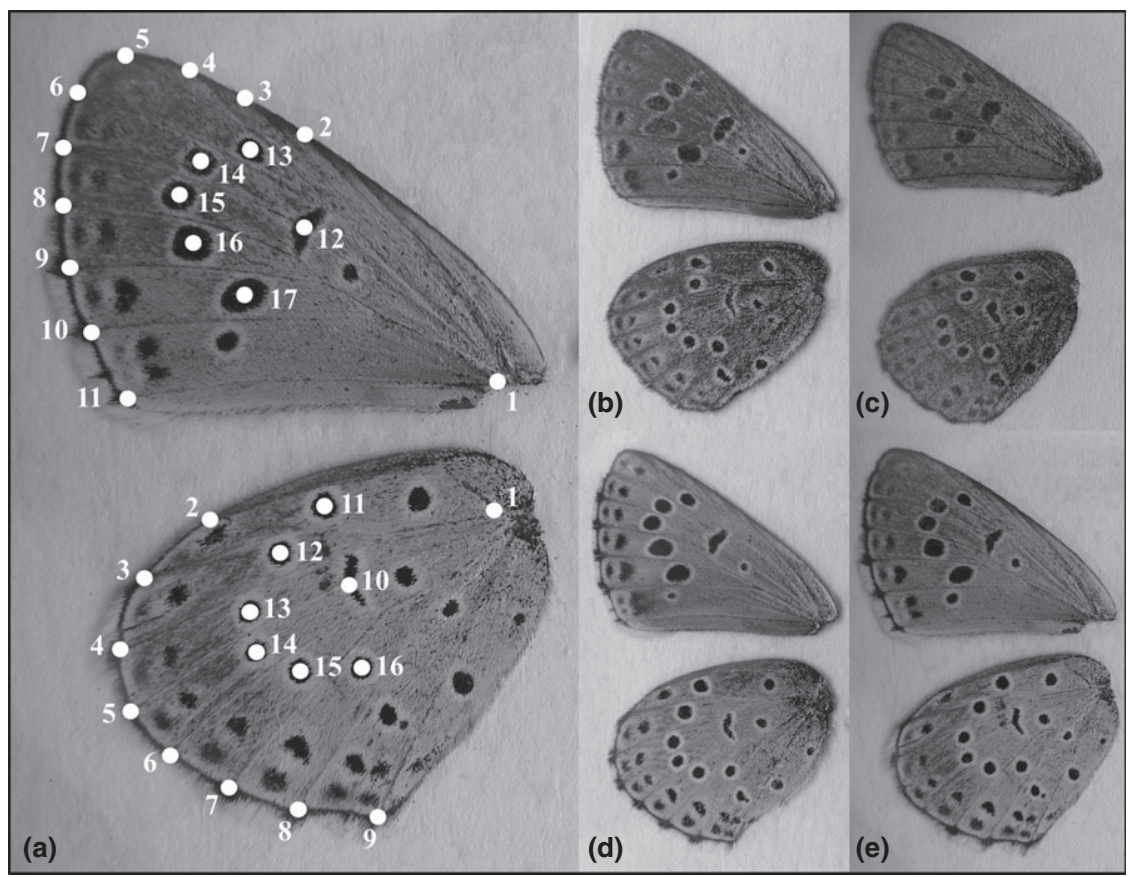

Fig. 2. Morphometric analyses. (a) landmarks on the underside of wings, (b) 'spring-type' wings from AZab; (c) 'spring-type' wings from AHar; (d) 'summer-type' wings from LZab; (e) 'summer-type' wings from LSin. See the abbreviations in Appendix 2

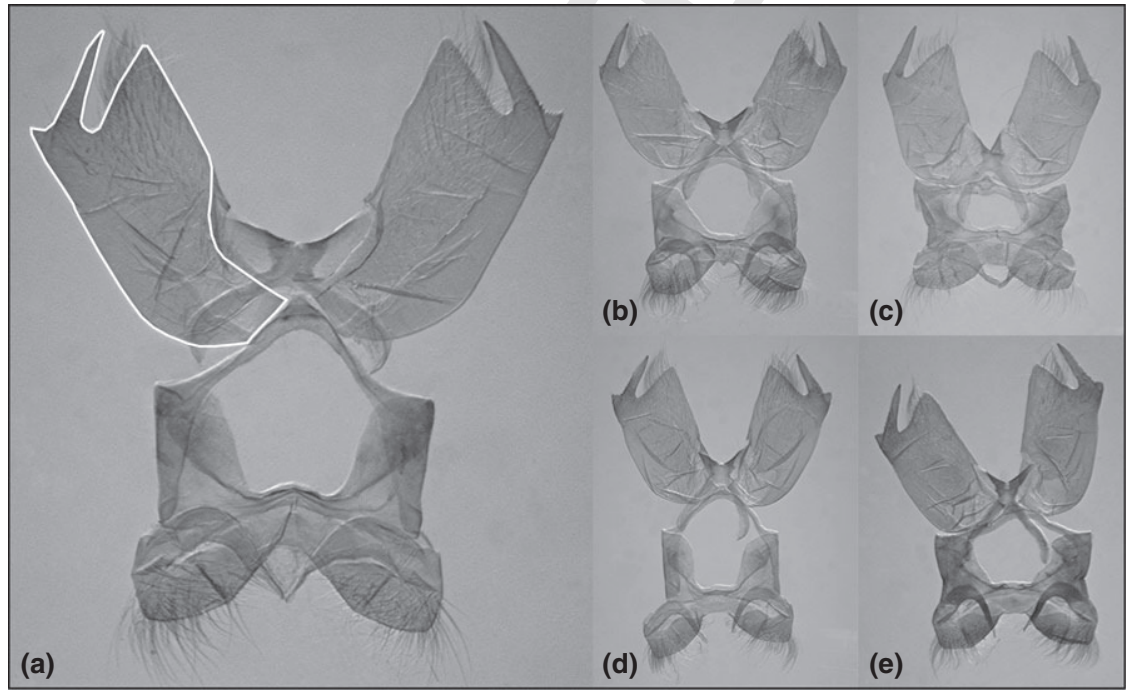

Fig. 3. Morphometric analyses. (a) closed curve on valva of genitalia; (b) 'spring-type' genitalia from AZab; (c) 'spring-type' genitalia from AHar; (d) 'summer-type' genitalia from LZab; (e) 'summer-type' genitalia from LSin. See the abbreviations in Appendix 2

were from COI and 856 bp were from COII. Altogether, there were 10 variable positions in the alignment of M. arion sequences and each was parsimony informative. All three different phylogenetic tree reconstruction methods yielded the same topology of phylogenetic trees (Fig. 4a,b). The 'spring' and the 'summer type' of $M$. arion were not differentiated on the basis of these mitochondrial sequences. Moreover, the target sequences did not show any geographical pattern. Only the two Slovenian individuals from Kamnik have been found on a well-supported sub-branch (bootstrap ML: 80\%; bootstrap MP: 85\%; Bayesian posterior probability: 0.99) although it should be noted that the differentiation of these specimens is attributable to altogether six mutations on 2217 sites. Outgroups were clearly separated from $M$. arion individuals. This lack of resolution within $M$. arion can be explained by infection with Wolbachia, which was proven by appropriate tests. All M. arion individuals were infected by Wolbachia supergroup A (Appendix 1), and M. alcon specimens were infected with B supergroup. M. nausithous was uninfected and we got a weak band indicating the infection by B supergroup in $M$. teleius.

The results of our previous allozyme study (Bereczki et al. 2011) have been confirmed by the recent analysis based on a reduced data set. The two types of $M$. arion were not separable at the enzyme level. All $M$. arion samples were located in the same branch of the dendrogram and they separated clearly from the outgroup (Fig. 4c). The samples from the same locality (AZab and LZab) did not cluster together. Pairwise $\mathrm{F}_{\mathrm{ST}}$ values indicated small differences among populations even between the 
(a) (a)
MP cladogram
based on COI and COII
AHar

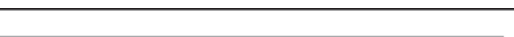

(b) based on $\mathrm{COI}$ and $\mathrm{COII}$

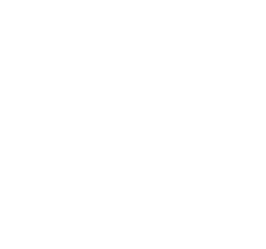

100

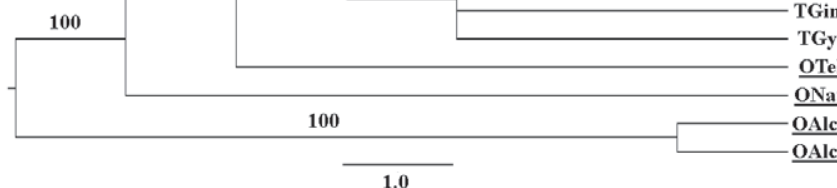

(c)

1.0

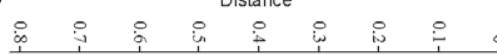

UPGMA dendrogram based on allozymes

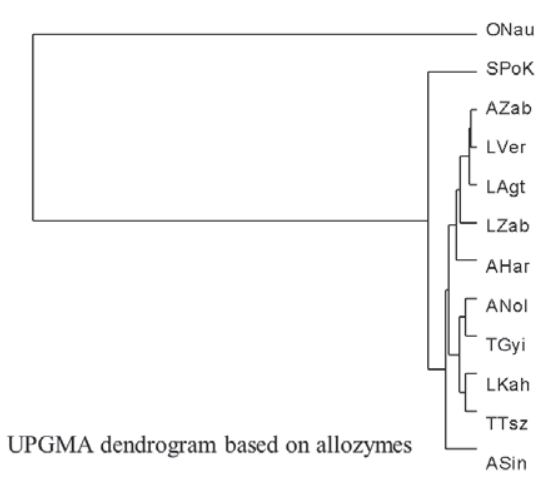

(d)

\begin{tabular}{l|l} 
F $_{\text {ST }}$ & AHar ANol ASin AZab LZab LAgt LKah LVer TGyi TTsz SPoK
\end{tabular} \begin{tabular}{l|lllllllllll} 
AHar & 0.000 & 0.051 & 0.087 & 0.051 & 0.052 & 0.038 & 0.081 & 0.047 & 0.031 & 0.049 & 0.112
\end{tabular} $\begin{array}{llllllllllll}\text { ANol } & 0.051 & 0.000 & 0.046 & 0.034 & 0.046 & 0.046 & 0.039 & 0.047 & 0.024 & 0.030 & 0.139\end{array}$ \begin{tabular}{l|lllllllllll} 
ASin & 0.087 & 0.046 & 0.000 & 0.040 & 0.045 & 0.066 & 0.073 & 0.069 & 0.078 & 0.071 & 0.118
\end{tabular} $\begin{array}{llllllllllll}\text { AZab } & 0.051 & 0.034 & 0.040 & 0.000 & 0.037 & 0.026 & 0.075 & 0.020 & 0.061 & 0.049 & 0.118\end{array}$ \begin{tabular}{l|lllllllllll} 
LZab & 0.052 & 0.046 & 0.045 & 0.037 & 0.000 & 0.027 & 0.051 & 0.046 & 0.057 & 0.038 & 0.083
\end{tabular} \begin{tabular}{l|lllllllllll} 
LAgt & 0.038 & 0.046 & 0.066 & 0.026 & 0.027 & 0.000 & 0.063 & 0.028 & 0.065 & 0.040 & 0.097
\end{tabular} \begin{tabular}{l|lllllllllll} 
LKah & 0.081 & 0.039 & 0.073 & 0.075 & 0.051 & 0.063 & 0.000 & 0.096 & 0.048 & 0.035 & 0.141
\end{tabular} \begin{tabular}{l|lllllllllll} 
LVer & 0.047 & 0.047 & 0.069 & 0.020 & 0.046 & 0.028 & 0.096 & 0.000 & 0.079 & 0.061 & 0.117
\end{tabular} \begin{tabular}{l|llllllllllll} 
TGyi & 0.031 & 0.024 & 0.078 & 0.061 & 0.057 & 0.065 & 0.048 & 0.079 & 0.000 & 0.039 & 0.147
\end{tabular} \begin{tabular}{l|lllllllllll} 
TTsz & 0.049 & 0.030 & 0.071 & 0.049 & 0.038 & 0.040 & 0.035 & 0.061 & 0.039 & 0.000 & 0.124
\end{tabular} \begin{tabular}{l|lllllllllll}
$\mathbf{S P o K}$ & 0.112 & 0.139 & 0.118 & 0.118 & 0.083 & 0.097 & 0.141 & 0.117 & 0.147 & 0.124 & 0.000
\end{tabular}

Pairwise $\mathrm{F}_{\mathrm{ST}}$ values based on allozymes

Fig. 4. The results of molecular studies. (a) Maximum parsimony cladogram based on the concatenated COI and COII sequences with bootstraps. See 20 the abbreviations in Appendix 1. (b) Bayesian cladogram based on the concatenated COI and COII sequences with clade credibility values. See the abbreviations in Appendix 1. (c) UPGMA dendrogram based on allozymes using Nei's genetic distances. See the abbreviations in Appendix 2. (d) Pairwise $\mathrm{F}_{\mathrm{ST}}$ values calculated on the basis of allozymes. See the abbreviations in Appendix 2.

samples which are located in different geographical regions at long distances apart. The separation of the Slovenian sample from all the other ones was the highest extent (Fig. 4d).

\section{Morphometric studies}

The repeatability of measurements was satisfactory ( $\mathrm{ME}<5 \%$ ) in most cases. The error was $<9 \%$ in the case of each hind-wing and genitalia coordinate. We excluded the landmarks of forewing from our analyses that have more than $20 \%$ measurement error.

The results of our morphometric survey were very similar in cases of wings and genitalia alike. The 'spring' and the 'summer arion' differentiated significantly (fore-wing: Wilks' $\lambda=0.253$, $\mathrm{p}<0.001$; hind-wing: Wilks' $\lambda=0.358, \mathrm{p}<0.001$; genitalia: Wilks' $\lambda=0.399, \mathrm{p}<0.001$ ). More than $85 \%$ of the individuals were correctly classified by a cross-validated method in both wings and genitalia (Appendix $3 \mathrm{~A}-\mathrm{C}$ ). The best classification was obtained in the case of fore-wing (the lowest Wilks' $\lambda$ with the highest classification value $-93.0 \%$ ).
The samples of the 'spring' and the 'summer arion' clustered separately both on the phenogram of wings (Fig. 5a,b) and on that of genitalia (Fig. 5c). The samples from the same locality (AZab and LZab) clustered separately according to the phenology. In cases of wings, a geographical pattern can be recognized. The Slovenian sample differentiated from the other ones at the highest extent in wings, but it is clustered together with one of the Transylvanian samples on the basis of genital traits. The group centroids of the two different types of $M$. arion samples also differentiated from each other at the first axis (Fig. 5d-f). Moreover, we experienced significant differences $(\mathrm{p}<0.001)$ in size between the 'spring' and 'summer arion'. The Transylvanian and Slovenian samples were clearly grouped into the 'summer arion' on the basis of size (Fig. $5 \mathrm{~g}-\mathrm{i}$ ).

\section{Discussion}

The genetic and morphometric patterns revealed by our studies are discordant. While we experienced significant differences in morphology between the 'spring' and 'summer type' of 

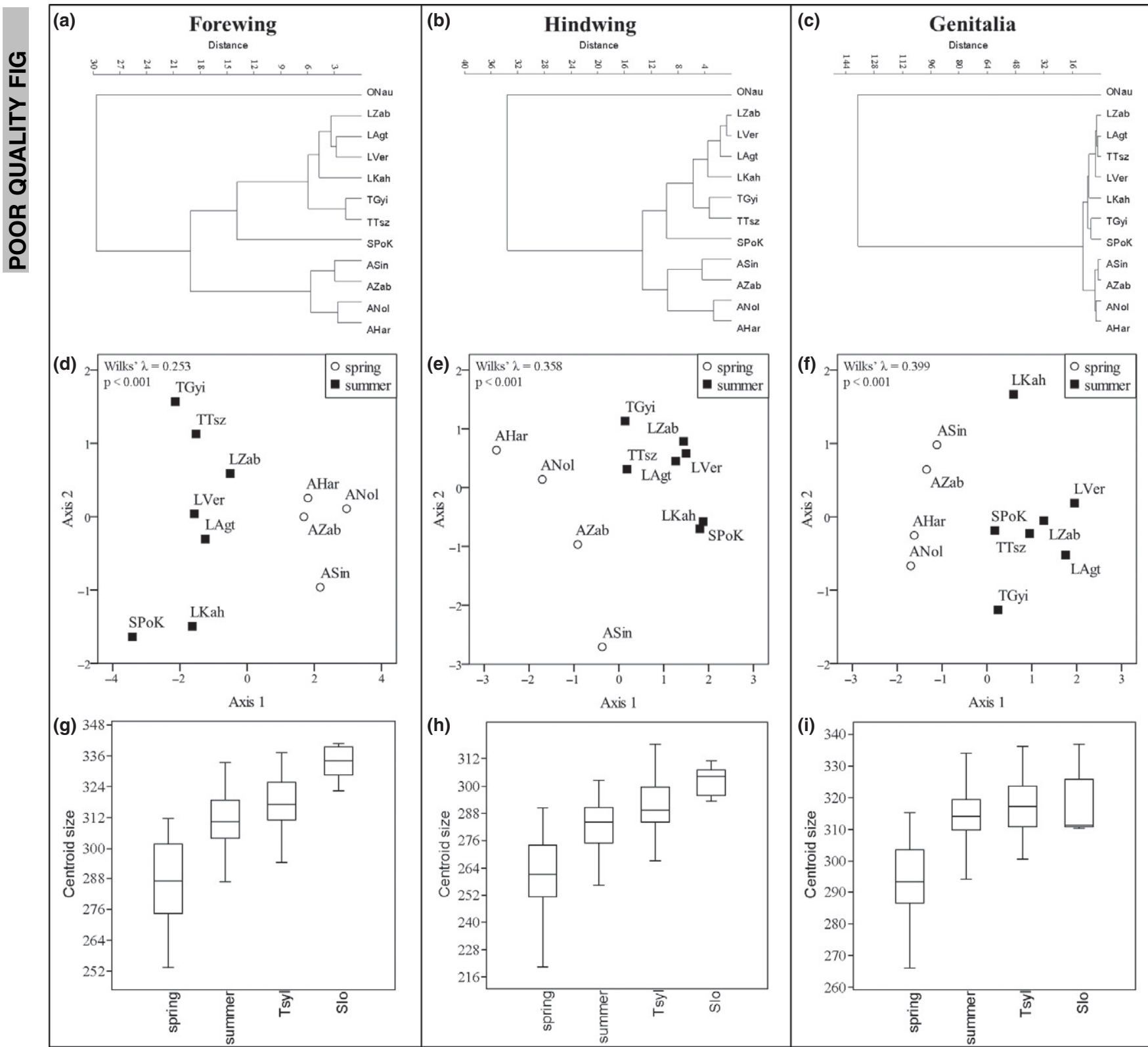

Fig. 5. The results of morphometric analyses. UPGMA phenograms based on Mahalanobis distances: (a) fore-wing, (b) hind-wing, (c) genitalia. On 21 the CVA scatterplots, the group centroids of samples are represented. See the abbreviations in Appendix 2. (d) fore-wing, (e) hind-wing, (f) genitalia. Box plots indicating the distribution of the centroid size. Spring - the 'spring arion'; summer - the 'summer arion'; Tsyl - Transylvanian samples; Slo - the Slovenian sample. (g) fore-wing, (h) hind-wing, (i) genitalia

M. arion, the two phenological forms show genetic differentiation neither on the mitochondrial sequence nor at the allozyme level.

The variability of the studied mitochondrial regions was highly reduced. Only the Slovenian specimens from Kamnik formed a highly supported clade nested within the otherwise unresolved clade of $M$. arion. At the same time, all $M$. arion specimens proved to be infected by Wolbachia A. M. alcon individuals, used here as outgroups, were also infected but with Wolbachia B. Similar to our results, Sielezniew (2012) and Sielezniew et al. (2012) reported the infection of the same types of Wolbachia and a reduced mtDNA diversity compared to nuclear variation in the populations of M. arion and M. alcon in Poland and Lithuania. Therefore, the lack of resolution within $M$. arion found here is presumably the consequence of indirect selection mediated by Wolbachia (Ballard and William 2000a; Jiggins 2003; Hurst and
Jiggins 2005) rather than that of population dynamic events. Thus, the usage of additional nuclear markers and regular assays for Wolbachia presence as well as multilocus sequence typing (MLST) should be applied in phylogenetic and phylogeographical studies despite the fact that Wolbachia COI was only present in $0.16 \%$ of $>2$ million insect COI sequences (Smith et al. 2012). Although detailed population dynamic studies (markrelease-recapture) were carried out only in one population from Vérteskozma ('LVer') in Hungary (Körösi et al. 2005) and sex ratio distortion was not recorded (Körösi, pers. comm.), further studies are needed to elucidate the possible effect and phenotype of Wolbachia in M. arion populations in the Carpathian Basin. Besides, it would be worth to use nuclear markers mostly in the couples of samples originated from the same locality.

On the basis of our allozymes studies, genetic differentiation among M. arion populations is low. The isolation of the 
Slovenian sample was the highest. Our results coincide with those of Polish authors based on microsatellites (Rutkowski et al. 2009; Sielezniew and Rutkowski 2012) who also experienced small and moderate differentiation among $M$. arion samples.

This pattern is probably in relation to the biological characteristics of this species. Only one or two larvae of $M$. arion may survive in an ant-nest, because one predatory caterpillar requires on average 350 ant workers to be raised compared with 50 for a 'cuckoo' larva (Elmes et al. 1991; Thomas and Wardlaw 1992). In addition, the majority of Myrmica species live in small colonies of 200-500 workers (Elmes et al. 1998) such as M. sabuleti, the primary host ant of $M$. arion in Western Europe. Therefore, only few Myrmica colonies are large enough to support just a single $M$. arion larva, and small colonies (or multiple infected large ones) are probably to be completely exploited by caterpillar (s) in the spring (Thomas and Wardlaw 1992), because they experience dramatic reductions in colony fitness by infection (Thomas et al. 1989). Consequently, the depleted colonies may be less suitable as a host for $M$. arion in the following year although the ant colony may be replaced by another one (Tolman and Lewington 2009). This intimate butterfly-ant relationship may lead to strong oscillations in population census size such as reported in the northernmost Finnish population (Kolev 1998) and in Vértes population in Hungary (LVer). In the latter population, approximately 300 individuals were marked in a two-ha area in 2002, but mark-release-recapture studies failed due to the absence of $M$. arion in 2004-2005 (Körösi et al. 2005). Consequently, the genetic diversity may primarily be maintained by gene flow among local low-density populations.

Additionally, M. arion has high dispersal ability, which has been revealed by capture-recapture studies (Pajari 1992). At the same time, molecular studies indicated that gene flow occurs over distances 15 times longer than the maximum distance recorded from mark-recapture studies, and $M$. arion can maintain fully functional metapopulations where the suitable habitat patches are not further apart than approximately $10 \mathrm{~km}$ (Ugelvig et al. 2011a, 2012). Therefore, the high potential of gene flow may also contribute to the low genetic differentiation found among $M$. arion populations.

Our morphometric research showed significant differences between the 'spring and summer arion' both in wings and in genitalia. In the case of wings, a geographical pattern was observed. Numerous studies revealed that certain wing traits for example size, melanization level - may be determined environmentally along climatic (latitudinal or altitudinal) gradients (Dennis 1977; Dennis and Shreeve 1989; Smyllie 1992) and greatly exposed to environmental stress (Talloen et al. 2009). Sielezniew and Dziekańska (2011) found that the melanization level was higher in the north-eastern part of Poland than in the South, and the mid-eastern region showed intermediate characteristics. At the same time, other wing traits are probably not exposed to environmental effects considerably, but determined rather by genetic factors (Talloen et al. 2009), for example the position of spots on the underside, which is used for the identification in Maculinea taxonomy (Sibatani et al. 1994). Since we experienced clear geographical pattern hardly explained by climatic factors, we suppose that the wing traits involved in our study are probably determined genetically rather than environmentally. Nonetheless, this pattern may also be in relation to the different host-ant use (Gadeberg and Boomsma 1997; Sielezniew and Dziekańska 2011; Sielezniew and Rutkowski 2012).

At the same time, good agreement has been revealed between the outcome of the molecular studies and that of male genitalia morphometrics in numerous analyses (Cesaroni et al. 1989, 1994; Garnier et al. 2005). This suggests that selective pressures controlling genital structures are relatively homogeneous across taxa and the patterns of divergence in genital morphology may reflect overall genetic divergence rather than differential adaptive responses. Consequently, the quantitative traits of male genitalia may be good estimators of the overall divergence among populations and closely related species and generally considered reliable taxonomic characteristics for traditional systematic work at the species level.

Our molecular and morphometric analyses lead to discordant results, but we have to consider some basic facts. First, the diversity of the barcoding gene is proved to be reduced presumably due to Wolbachia infection. Second, the allozymes of Maculinea species are generally less polymorphic than those of other European lycaenid species (Schmitt and Seitz 2001, 2002a,b; Aagaard et al. 2002; Schmitt et al. 2002, 2003, 2005; Schmitt and Hewitt 2004). Therefore, it is possible that allozyme and mitochondrial DNA studies are not suitable for the detection of the divergence between the 'spring and summer arion'. Nevertheless, our morphometric studies have revealed significant differences between $M$. a. arion and $M$. a. ligurica. Although certain wing traits may not represent reliable tracers of phylogeny because of their particular adaptive significance, the wing characteristics involved in our research are probably determined genetically. Additionally, the significant differentiation of male genitalia also indicates incipient prezygotic isolation arising from phenological differentiation between the two types of $M$. arion.

In summary, our study clearly indicates that the combined use of different approaches and data sets is highly necessary to clarify systematic and evolutionary relationships among taxa despite the fact that molecular data often tend to receive more emphasis than morphological ones. Although we did not find differences between the two forms of $M$. arion on the basis of molecular data, it is not at all unlikely that our markers are not suitable for the detection of the divergence between them. It is possible that all extant differences of the two forms are attributable to (1) different host-ant use, (2) incipient speciation, (3) CI by Wolbachia or a combination of these factors. Further molecular and ecological studies are needed to elucidate the pattern of variation.

\section{Acknowledgements}

The study was supported by the OTKA (K-84071), TÁMOP-4.2.2/B-10/ 1-2010-0024 and TÁMOP 4.2.4.A/2-11-1-2012-0001 projects. Grateful acknowledgements are due to László Peregovits and Sándor Szabó for collecting samples. The support of the Nature Conservation Authorities of Hungary is also greatly appreciated.

\section{Zusammenfassung}

Der gefährdete sozialparasitische Bläuling Maculinea arion stand im Vordergrund dieser naturschutzbiologischen Untersuchungen. In der vorliegenden Arbeit werden die Unterschiede zwischen den phänologischen Formen von Maculinea arion aufgrund von vier verschiedenen Merkmalsgruppen (mitochondriale Sequenzen, Allozyme, Morphometrie der männlichen Genitalien und Flügelmuster) besprochen. Distanzmatrizes, phylogenetische Bäume und Ordinationsmuster werden verglichen. Wir haben gegensätzliche Ergebnisse in der genetischen bzw. morphometrischen Differenzierungen erhalten. Während in den morphometrischen Merkmalen der Flügel und Genitalien erhebliche Unterschiede zwischen den phänologischen 'Frühjahrs-' und 'Sommer'-Formen gefunden wurden, zeigten die beiden mitochondrialen Loci und auch das Allozymmuster keine Differenzierung. Alle untersuchten Individuen waren jedoch mit Wolbachia infiziert. Obwohl die meisten Flügelmerkmale wegen ihrer adaptiven Plastizität phylogenetisch als irrelevant gelten, sollten die von uns gewählten Merkmale einen genetischen Hintergrund haben. Außerdem deuten die nachgewiesenen Unterschiede in den männlichen Genitalien auf eine anfängliche präzygotische Isolation zwischen den beiden 
phänologischen Formen hin. Als mögliche Gründe für eine solche Differenzierung könnten (1) die verschiedenen Wirtsameisen, (2) beginnende Speziation bzw. (3) zytoplasmatische Inkompatibilität durch Wolbachia oder die Kombination diese Faktoren gelten. Die gegensätzlichen Ergebnisse sollten die Notwendigkeit der kombinierten Anwendung verschiedener Methoden und Datensätze in der Untersuchung der systematischen und evolutionären Verhältnisse unterstreichen.

\section{References}

Aagaard K, Hindar K, Pullin AS, et al. (2002) Phylogenetic relationships in brown argus butterflies (Lepidoptera: Lycaenidae: Aricia) from 10 northwestern Europe. Biol J Linn Soc 75:27-37.

Als TD, Vila R, Kandul NP, et al. (2004) The evolution of alternative parasitic life histories in large blue butterflies. Nature 432:386-390.

Bailey RC, Byrnes J (1990) A new, old Method for assessing measurement error in both univariate and multivariate morphometric studies. Syst Biol 39:124-130.

Ballard J, William O (2000a) Comparative genomics of mitochondrial DNA in Drosophila simulans. J Mol Evol 51:64-75.

Ballard J, William O (2000b) Comparative genomics of mitochondrial DNA in members of the Drosophila melanogaster subgroup. J Mol Evol 51:48-63.

Balletto E, Bonelli S, Settele J, Thomas J, Verovnik R, Wahlberg N (2010) Case 3508 Maculinea Van Eecke, 1915 (Lepidoptera: LYCAENIDAE): proposed precedence over Phengaris Doherty, 1891. Bull Zool Nomencl 67:129-132.

Bereczki J, Pecsenye K, Peregovits L, Varga Z (2005) Pattern of genetic differentiation in the Maculinea alcon species group (Lepidoptera, Lycaenidae) in Central Europe. J Zoolog Syst Evol Res 43:157-165.

Bereczki J, Tóth JP, Tóth A, Bátori E, Pecsenye K, Varga Z (2011) The genetic structure of phenologically differentiated Large Blue (Maculinea arion) populations (Lepidoptera: Lycaenidae) in the Carpathian Basin. Eur J Entomol 108:519-527.

Cesaroni D, Allegrucci G, Angelici MC, Racheli T, Sbordoni V (1989) Allozymic and morphometric analysis of populations in the Zygaena purpuralis complex (Lepidoptera, Zygaenidae). Biol J Linn Soc 36:271-280.

Cesaroni D, Lucarelli M, Allori P, Russo F, Sbordoni V (1994) Patterns of evolution and multidimensional systematics in graylings (Lepidoptera, Hipparchia). Biol J Linn Soc 52:101-119.

Cheshire S (2011) British Butterflies: Species: Species Account - The Large Blue. Available at http://www.britishbutterflies.co.uk/species-info.

11 asp?vernacular=Large+Blue. Last accessed $\mathrm{xx}$ Xxxxxx 20xx.

Claude J (2008) Morphometrics with R. Springer Science+Business Media, LLC, New York, NY.

Dapporto L, Bruschini C, Baracchi D, et al. (2009) Phylogeography and counter-intuitive inferences in island biogeography: evidence from morphometric markers in the mobile butterfly Maniola jurtina (Linnaeus) (Lepidoptera, Nymphalidae). Biol J Linn Soc 98:677-692.

Dapporto L, Schmitt T, Vila R, et al. (2011) Phylogenetic island disequilibrium: evidence for ongoing long-term population dynamics in two Mediterranean butterflies. J Biogeogr 38:854-867.

Dennis RLH (1977) The British Butterflies. Their Origin and Establishment. E. W. Classey Ltd., Faringdon, Oxon.

Dennis RLH, Shreeve TG (1989) Butterfly wing morphology variation in the British Isles: the influence of climate, behavioural posture and the hostplant-habitat. Biol J Linn Soc 38:323-348.

Dinca V, Zakharov EV, Hebert PDN, Vila R (2010) Complete DNA barcode reference library for a country's butterfly fauna reveals high performance for temperate Europe. Proc R Soc B 278:347-355.

Dinca V, Dapporto L, Vila R (2011) A combined genetic-morphometric analysis unravels the complex biogeographical history of Polyommatus icarus and Polyommatus celina Common Blue butterflies. Mol Ecol 20:3921-3935.

Drummond A, Rambaut A (2007) BEAST: Bayesian evolutionary analysis by sampling trees. BMC Evol Biol 7:214.

Ebach MC, Holdrege C (2005) DNA barcoding is no substitute for taxonomy. Nature 434:697.

Elmes GW, Wardlaw JC, Thomas JA (1991) Larvae of Maculinea rebeli, a large-blue butterfly and their Myrmica host ants: patterns of caterpillar growth and survival. J Zool 224:79-92.
Elmes GW, Thomas JA, Wardlaw JC, Hochberg ME, Clarke RT, Simcox DJ (1998) The ecology of Myrmica ants in relation to the conservation of Maculinea butterflies. J Insect Conserv 2:67-78.

Fleishman E, Thomson JR, Mac Nally R, Murphy DD, Fay JP (2005) Using indicator species to predict species richness of multiple taxonomic groups. Utilización de especies indicadoras para predecir la riqueza de especies de múltiples grupos taxonómicos. Conserv Biol 19:1125-1137.

Fric Z, Wahlberg N, Pech P, Zrzavý JAN (2007) Phylogeny and classification of the Phengaris-Maculinea clade (Lepidoptera: Lycaenidae): total evidence and phylogenetic species concepts. Syst Entomol 32:558-567.

Gadeberg RME, Boomsma JJ (1997) Genetic population structure of the large blue butterfly Maculinea alcon in Denmark. J Insect Conserv 1:99-111.

Garnier S, Magniez-Jannin F, Rasplus JY, Alibert P (2005) When morphometry meets genetics: inferring the phylogeography of Carabus solieri using Fourier analyses of pronotum and male genitalia. J Evol Biol 18:269-280.

Giardina CR, Kuhl FP (1977) Accuracy of curve approximation by harmonically related vectors with elliptical loci. Comput Graphics Image Process 6:277-285.

Gilbert MTP, Moore W, Melchior L, Worobey M (2007) DNA extraction from dry museum beetles without conferring external morphological damage. PLoS ONE 2:e272.

Goffart P (1997) Libellules et papillons en Wallonie. Université Catholique de Louvain-la-Neuve, Louvain-la-Neuve.

Gompert Z, Forister ML, Fordyce JA, Nice CC (2008) Widespread mitonuclear discordance with evidence for introgressive hybridization and selective sweeps in Lycaeides. Mol Ecol 17:5231-5244.

Hammer Ø, Harper DAT, Ryan PD (2001) PAST: Paleontological Statistics software package for education and data analysis. Paleontol Electronica 4:9.

Hebert PDN, Ratnasingham S, de Waard JR (2003) Barcoding animal life: cytochrome $\mathrm{c}$ oxidase subunit 1 divergences among closely related species. Proc R Soc Lond B Biol Sci 270:S96-S99.

Hebert PDN, Penton EH, Burns JM, Janzen DH, Hallwachs W (2004) Ten species in one: DNA barcoding reveals cryptic species in the neotropical skipper butterfly Astraptes fulgerator. Proc Natl Acad Sci USA 101:14812-14817.

Higgins LG, Riley ND (1970) Die Tagfalter Europas und Nordwestafrikas. Verlag Paul Parey, Hamburg und Berlin.

Hoffmann A, Turelli M (1997) Cytoplasmic Incompatibility in Insects. Oxford University Press, Oxford.

Hurst GDD, Jiggins FM (2005) Problems with mitochondrial DNA as a marker in population, phylogeographic and phylogenetic studies: the effects of inherited symbionts. Proc R Soc B Biol Sci 272:1525-1534.

Hurst GDD, Jiggins FM, Hinrich Graf von der Schulenburg J, et al. (1999a) Male-killing Wolbachia in two species of insect. Proc R Soc Lond B Biol Sci 266:735-740.

Hurst GDD, von der Schulenburg JHG, Majerus TMO, et al. (1999b) Invasion of one insect species, Adalia bipunctata, by two different male-killing bacteria. Insect Mol Biol 8:133-139.

Jiggins FM (2003) Male-killing Wolbachia and mitochondrial DNA: selective sweeps, hybrid introgression and parasite population dynamics. Genetics 164:5-12.

Kolev Z (1998) Maculinea arion (L.) in Finland-distribution, state of knowledge and conservation. J Insect Conserv 2:91-93.

Kőrösi Á, Peregovits L, Örvössy N, Vozár Á, Kassai F (2005) Studying the population structure of Maculinea arion ligurica. Studies on the Ecology and Conservation of Butterflies in Europe. Volume 2: Species Ecology along a European Gradient: Maculinea Butterflies as a Model. Proceedings of the Conference held in UFZ Leipzig.

Kuhl FP, Giardina CR (1982) Elliptic Fourier features of a closed contour. Comput Graphics Image Process 18:236-258.

Kumar S, Skjaeveland A, Orr R, et al. (2009) AIR: a batch-oriented web program package for construction of supermatrices ready for phylogenomic analyses. BMC Bioinformatics 10:357.

Lessells CM, Boag PT (1987) Unrepeatable repeatabilities: a common mistake. Auk 104:116-121.

Monteiro A, Pierce NE (2001) Phylogeny of Bicyclus (Lepidoptera: Nymphalidae) Inferred from COI, COII, and EF-1 $\alpha$ Gene Sequences. Mol Phylogenet Evol 18:264-281. 
Munguira ML, Martin J (1997) Action Plan for the Maculinea Butterflies

Narita S, Nomura M, Kageyama D (2007) Naturally occurring single and double infection with Wolbachia strains in the butterfly Eurema hecabe: transmission efficiencies and population density dynamics of each Wolbachia strain. FEMS Microbiol Ecol 61:235-245.

Nei M (1975) Molecular Population Genetics and Evolution. NorthHolland Publishing Company, Amsterdam.

Nice CC, Gompert Z, Forister ML, Fordyce JA (2009) An unseen foe in arthropod conservation efforts: the case of Wolbachia infections in the Karner blue butterfly. Biol Conserv 142:3137-3146.

Nylander JAA (2004) MrModeltest 2.3. Program Distributed by the

13 Author. Evolutionary Biology Centre, Uppsala University, ??????

Pajari M (1992) Muurahaissinisiiven (Maculinea arion (L.)) populaatiokoon arviointi ja habitaattivaatimusten tutkiminen kesalla 1990 Pohjois-Karjalan Liperissa. [An estimation of the population size and habitat demands of Maculinea arion during the summer of 1990 in

14 Liperi, North Karelia.] University of Joensuu, ???????

Peakall ROD, Smouse PE (2006) Genalex 6: genetic analysis in Excel Population genetic software for teaching and research. Mol Ecol Notes 6:288-295.

Posada D, Crandall KA (1998) Modeltest: testing the model of DNA substitution. Bioinformatics 14:817-818.

R Development Core Team (2010) R: A Language and Environment for Statistical Computing. R Foundation for Statistical Computing, Vienna, Austria.

Robinson GS (1976) The preparation of slides of Lepidoptera genitalia with special reference to the Microlepidoptera. Entomol Gaz 27: 127-132.

Ronquist F, Teslenko M, van der Mark P, et al. (2012) MrBayes 3.2 efficient Bayesian phylogenetic inference and model choice across a

15 large model space. Syst Biol 61:????-????

Rutkowski R, Sielezniew M, Szostak A (2009) Contrasting levels of polymorphism in cross-amplified microsatellites in two endangered xerothermophilous, obligatorily myrmecophilous, butterflies of the genus Phengaris (Maculinea) (Lepidoptera: Lycaenidae). Eur J Entomol 106:457-469.

Sasaki T, Kubo T, Ishikawa H (2002) Interspecific transfer of Wolbachia between two Lepidopteran insects expressing cytoplasmic incompatibility: a Wolbachia variant naturally infecting Cadra cautella causes male killing in Ephestia kuehniella. Genetics 162:1313-1319.

Schmitt T, Hewitt GM (2004) The genetic pattern of population threa and loss: a case study of butterflies. Mol Ecol 13:21-31.

Schmitt T, Seitz A (2001) Allozyme variation in Polyommatus coridon (Lepidoptera: Lycaenidae): identification of ice-age refugia and reconstruction of post-glacial expansion. J Biogeogr 28:1129-1136.

Schmitt T, Seitz A (2002a) Influence of habitat fragmentation on the genetic structure of Polyommatus coridon (Lepidoptera: Lycaenidae) implications for conservation. Biol Conserv 107:291-297.

Schmitt T, Seitz A (2002b) Postglacial distribution area expansion of Polyommatus coridon (Lepidoptera: Lycaenidae) from its PontoMediterranean glacial refugium. Heredity 89:20-26.

Schmitt T, Giesl A, Seitz A (2002) Postglacial colonisation of western Central Europe by Polyommatus coridon (Poda 1761) (Lepidoptera: Lycaenidae): evidence from population genetics. Heredity 88:26-34.

Schmitt T, Giessl A, Seitz A (2003) Did Polyommatus icarus (Lepidoptera: Lycaenidae) have distinct glacial refugia in southern Europe? Evidence from population genetics. Biol J Linn Soc 80: 529-538.

Schmitt T, Varga Z, Seitz A (2005) Are Polyommatus hispana and Polyommatus slovacus bivoltine Polyommatus coridon (Lepidoptera: Lycaenidae)? The discriminatory value of genetics in taxonomy. Org Div Evol 5:297-307.

Settele J, Kühn E, Thomas JA (2005) Studies on the Ecology and Conservation of Butterflies in Europe. Vol. 2: Species ecology along a European gradient: Maculinea butterflies as a model. Pensoft Publishers, Sofia-Moscow.

Shaikevich EV, Vinogradova EB, Platonov AE, Karan LS, Zakharov IA (2005) Polymorphism of mitochondrial DNA and infection with symbiotic cytoplasmic bacterium Wolbachia pipientis in mosquitoes of the Culex pipiens (Diptera, Culicidae) complex from Russia. Russ J Genet 41:244-248.
Shoemaker D, Keller G, Ross KG (2003) Effects of Wolbachia on mtDNA variation in two fire ant species. Mol Ecol 12:1757-1771.

Sibatani A, Saigusa T, Hirowatari T (1994) The genus Maculinea van Eecke, 1915 (Lepidoptera: Lycaenidae) from the East Palaearctic Region.

Sielezniew M (2012) Setting of Priorities in Conservation of Phengaris (Maculinea) Butterflies at the Regional Scale using Ecological and Genetic Data. Future of butterflies in Europe III. Wageningen, Netherlands.

Sielezniew M, Dziekańska I (2011) Geographical variation in wing pattern in Phengaris (=Maculinea) arion (L.) (Lepidoptera: Lycaenidae): subspecific differentiation or clinal adaptation? Ann Zool 61:739-750.

Sielezniew M, Rutkowski R (2012) Population isolation rather than ecological variation explains the genetic structure of endangered myrmecophilous butterfly Phengaris (=Maculinea) arion. J Insect Conserv 16:39-50.

Sielezniew M, Stankiewicz AM (2008) Myrmica sabuleti (Hymenoptera: Formicidae) not necessary for the survival of the population of Phengaris (Maculinea) arion (Lepidoptera: Lycaenidae) in eastern Poland: Lower host-ant specificity or evidence for geographical variation of an endangered social parasite? Eur J Entomol 105:637-641.

Sielezniew M, Stankiewicz A, Bystrowski C (2003) First observation of one Maculinea arion pupa in a Myrmica lobicornis nest in Poland. Nota Lepidopterol 25:249-250.

Sielezniew M, Dziekańska I, Stankiewicz-Fiedurek A (2010a) Multiple host-ant use by the predatory social parasite Phengaris (=Maculinea) arion (Lepidoptera, Lycaenidae). J Insect Conserv 14:141-149.

Sielezniew M, Patricelli D, Dziekaska I, et al. (2010b) The first record of Myrmica lonae (Hymenoptera: Formicidae) as a host of the socially parasitic Large Blue butterfly Phengaris (Maculinea)* arion (Lepidoptera: Lycaenidae). Sociobiology 56:465-476.

Sielezniew M, Włostowski M, Dziekańska I (2010c) Myrmica schencki (Hymenoptera: Formicidae) as the primary host of Phengaris (Maculinea) arion (Lepidoptera: Lycaenidae) at heathlands in Eastern Poland. Sociobiology 55:95-106.

Sielezniew M, Rutkowski R, Ponikwicka-Tyszko D, Ratkiewicz M, Dziekańska I, Švitra G (2012) Differences in genetic variability between two ecotypes of the endangered myrmecophilous butterfly Phengaris (=Maculinea) alcon - the setting of conservation priorities. Insect Conserv Divers 5:223-236.

Smith MA, Bertrand C, Crosby K, et al. (2012) Wolbachia and DNA barcoding insects: patterns, potential, and problems. PLoS ONE 7: e36514.

Smyllie B (1992) The brown argus butterfly in Britain - range of Aricia hybrids. Entomologist 111:27-37.

Sneath PH, Sokal RR (1973) Numerical Taxonomy. W. H. Freeman, San Francisco, CA.

Spitzer L, Benes J, Dandova J, Jaskova V, Konvicka M (2009) The Large Blue butterfly, Phengaris [Maculinea] arion, as a conservation umbrella on a landscape scale: the case of the Czech Carpathians. Ecol Ind 9:1056-1063.

Swofford DL (2003) PAUP*. Phylogenetic Analysis Using Parsimony (*and Other Methods). Version 4. Sinauer Associates, Sunderland, MA.

Talloen W, Dongen S, Dyck H, Lens L (2009) Environmental stress and quantitative genetic variation in butterfly wing characteristics. Evol Ecol 23:473-485.

Tartally A (2008) Myrmecophily of Maculinea butterflies in the Carpathian Basin (Lepidoptera: Lycaenidae). Department of Evolutionary Zoology and Human Biology, University of Debrecen, ??????

Tax MH (1989) Atlas van de Nederlandse Dagvlinders. De Vlinderstichting, Wageningen and Stichting tot Behoud van Natuurmonumenten, s'-Graveland.

Thomas JA (1995) The ecology and conservation of Maculinea arion and other European species of large blue butterfly. In: Pullin AS (ed.), Ecology and Conservation of Butterflies. Chapman \& Hall, London, pp 180-196.

Thomas JA (1996) Maculinea arion (Linnaeus, 1758). In: Van Helsdingen PJ, Willemse L, Speight MCD (eds), Background Information on Invertebrates of the Habitats Directive and the Bern 
Convention. Part I - Crustacea, Coleoptera and Lepidoptera - Nature and Environment No 79. Council of Europe Publishing, Strasbourg, pp 157-163.

Thomas JA, Wardlaw JC (1992) The capacity of a Myrmica ant nest to support a predacious species of Maculinea butterfly. Oecologia 91:101-109.

Thomas JA, Elmes GW, Wardlaw JC, Woyciechowski M (1989) Host specificity among Maculinea butterflies in Myrmica ant nests. Oecologia 79:425-457.

Tolman T, Lewington R (2009) Collins Butterfly Guide: the most Complete Field Guide to the Butterflies of Britain and Europe. Harper Collins, London.

Turelli M, Hoffmann AA (1991) Rapid spread of an inherited incompatibility factor in California Drosophila. Nature 353:440-442.

Ugelvig L, Nielsen P, Boomsma J, Nash D (2011a) Reconstructing eight decades of genetic variation in an isolated Danish population of the large blue butterfly Maculinea arion. BMC Evol Biol 11:201.

Ugelvig LV, Vila R, Pierce NE, Nash DR (2011b) A phylogenetic revision of the Glaucopsyche section (Lepidoptera: Lycaenidae), with special focus on the Phengaris-Maculinea clade. Mol Phylogenet Evol 61:237-243.

Ugelvig LV, Andersen A, Boomsma JJ, Nash DR (2012) Dispersal and gene flow in the rare, parasitic Large Blue butterfly Maculinea arion. Mol Ecol 21:3224-3236.

Van Swaay C, Warren M, Grill A (1998) Convention on the Conservation of European Wildlife and Natural Habitats: Threatened

Butterflies in Europe Strasbourg. ???????, ??????
Van Swaay C, Cuttelod A, Collins S, et al. (2010) European Red List of Butterflies. Publications Office of the European Union, Luxembourg.

Varga Z (2010) Magyarország nagylepkéi [Macrolepidoptera of Hungary]. Heterocera Press, Budapest.

Verity R (1940-1953) Le farfalle diurne d'Italia. [Butterflies of Italy.] Marzocco, Firenze. (In Italian).

Wahlberg N, Wheat CW (2008) Genomic outposts serve the phylogenomic pioneers: designing novel nuclear markers for genomic DNA extractions of Lepidoptera. Syst Biol 57:231-242.

Werren JH, Windsor DM (2000) Wolbachia infection frequencies in insects: evidence of a global equilibrium? Proc R Soc Lond B Biol Sci 267:1277-1285.

Werren JH, Zhang W, Guo LR (1995) Evolution and phylogeny of Wolbachia: reproductive parasites of Arthropods. Proc R Soc Lond B Biol Sci 261:55-63.

Werren JH, Baldo L, Clark ME (2008) Wolbachia: master manipulators of invertebrate biology. Nat Rev Microbiol 6:741-751.

Wiemers M, Fiedler K (2007) Does the DNA barcoding gap exist? - a case study in blue butterflies (Lepidoptera: Lycaenidae). Front Zool 4:8.

Wynhoff I (1998) REVIEW: the recent distribution of the European Maculinea species. J Insect Conserv 2:15-27.

Yezerinac SM, Lougheed SC, Handford P (1992) Measurement error and morphometric studies: statistical power and observer experience. Syst Biol 41:471-482.

Appendix 1. Information on the specimens used in the DNA studies

\begin{tabular}{|c|c|c|c|c|c|}
\hline Taxa & Locality & Abbr. & Sampling time & DNA extraction & Wolbachia supergroup \\
\hline \multirow[t]{9}{*}{ Spring arion (Hungary) } & Almás-tető & AAlm & 2011-05-26 & Thorax & A \\
\hline & Boszorkány-völgy & ABos & $2011-05-25$ & Thorax & A \\
\hline & Haragistya & AHar & 2011-05-31 & Thorax & A \\
\hline & Kánó & AKan & 2011-05-24 & Thorax & A \\
\hline & Korlát-hegy & AKor & $2011-05-25$ & Thorax & A \\
\hline & Perkupa & APer & $2011-05-28$ & Thorax & A \\
\hline & Sóshartyán & ASos & $2002-05-19$ & Head & A \\
\hline & Szin & ASin & 2011-05-25 & Thorax & A \\
\hline & Zabanyik & AZab & 2011-05-24 & Thorax & A \\
\hline \multirow[t]{8}{*}{ Summer arion (Hungary) } & Aggtelek & LAgt & $2002-08-06$ & Head & A \\
\hline & Kaszonyi hegy & LKah & $2002-07-23$ & Head & A \\
\hline & Korlát-hegy & LKor & 2011-08-05 & Thorax & A \\
\hline & Perkupa & LPer & 2011-08-04 & Thorax & A \\
\hline & Szin & LSin & 2011-08-02 & Thorax & A \\
\hline & Szőlőhegy & LSol & 2011-07-14 & Thorax & A \\
\hline & Vérteskozma & LVer & $2002-07-10$ & Head & A \\
\hline & Zabanyik & LZab & 2011-08-03 & Thorax & A \\
\hline \multirow[t]{2}{*}{ Summer arion (Transylvania) } & Gyilkos tó & TGyi & $2002-07-02$ & Head & A \\
\hline & Gyimesbükk & TGim & 2011-07-16 & Thorax & A \\
\hline \multirow[t]{5}{*}{ Summer arion (Slovenia) } & Kamnik & SKam1 & 2003-07-04 & Head & A \\
\hline & & SKam2 & 2003-07-04 & Head & A \\
\hline & Polovnik & SPol1 & $2002-07-12$ & Head & A \\
\hline & & SPol2 & $2002-07-12$ & Head & A \\
\hline & & SPol3 & 2003-07-04 & Head & A \\
\hline \multirow[t]{2}{*}{ M. alcon } & Tohonya-hát & OAlc1 & 2011-06-23 & Thorax & B \\
\hline & Hochschwab & OAlc2 & $2003-07-11$ & Head & B \\
\hline M. nausithous & Kétvölgy & ONau & 2003-08-01 & Head & - \\
\hline M. teleius & Aggtelek & OTel & $2005-07-29$ & Thorax & ? \\
\hline
\end{tabular}

Abbr.: the abbreviations of localities (Fig. 1). See in boldface the couples of 'spring and summer arion' from the same locality. Wolbachia supergroup: the type of Wolbachia infection. 
Appendix 2. Information on the samples used in the allozyme and morphometric analyses

\begin{tabular}{lllr}
\hline Taxa & Locality & Abbr. & Sampling time \\
\hline Spring arion (Hungary) & Haragistya & AHar & $2005-06-06 / 07$ \\
& Nagyoldal & ANol & $2003-05-28 ; 2004-06-09$ \\
& Szin & ASin & $2011-05-25$ \\
& Zabanyik & AZab & $2005-05-30 ; 2005-06-05 / 06 ; 2011-05-24$ \\
Summer arion (Hungary) & Zabanyik & LZab & $2005-07-28,29 ; 2011-07-14$ \\
& Aggtelek & LAgt & $2005-07-28 / 29$ \\
& Kaszonyi hill & LKah & $2003-07-21 ; 2003-08-05$ \\
Summer arion (Transylvania) & Vérteskozma & LVer & $2002-07-01 / 03 ; 2003-07-02 / 07$ \\
& Lake Gyilkos & TGyi & $2004-07-24$ \\
Summer arion (Slovenia) & Torockószentgyörgy & TTsz & $2004-07-22 / 23$ \\
M. nausithous (outgroup) & Polovnik, Kamnik & SPoK & $2002-07-12 ; 2003-07-04$ \\
Total & Kétvölgy & ONau & $2004-08-05$
\end{tabular}

Abbr.: the abbreviations of localities (Fig. 1). See in boldface the pair of samples from the same syntopic population. N: number of individuals.

Appendix 3. Classification results of the canonical variates analysis (CVA)

\begin{tabular}{|c|c|c|c|c|}
\hline & \multicolumn{4}{|c|}{ Classification results ${ }^{1,2}$} \\
\hline & \multirow[b]{2}{*}{ Type } & \multicolumn{3}{|c|}{ Predicted group membership } \\
\hline & & 1 & 2 & Total \\
\hline \multicolumn{5}{|c|}{ (A) Fore-wing } \\
\hline \multicolumn{5}{|c|}{ Original } \\
\hline \multirow{2}{*}{ Count } & Spring & 56 & 4 & 60 \\
\hline & Summer & 4 & 79 & 83 \\
\hline \multirow[t]{2}{*}{$\%$} & Spring & 93.3 & 6.7 & 100.0 \\
\hline & Summer & 4.8 & 95.2 & 100.0 \\
\hline \multicolumn{5}{|c|}{ Cross-validated $^{3}$} \\
\hline \multirow[t]{2}{*}{ Count } & Spring & 55 & 5 & 60 \\
\hline & Summer & 5 & 78 & 83 \\
\hline \multirow[t]{2}{*}{$\%$} & Spring & 91.7 & 8.3 & 100.0 \\
\hline & Summer & 6.0 & 94.0 & 100.0 \\
\hline \multicolumn{5}{|c|}{ (B) Hind-wing } \\
\hline \multicolumn{5}{|c|}{ Original } \\
\hline \multirow[t]{2}{*}{ Count } & Spring & 51 & 9 & 60 \\
\hline & Summer & 5 & 78 & 83 \\
\hline \multirow[t]{2}{*}{$\%$} & Spring & 85.0 & 15.0 & 100.0 \\
\hline & Summer & 6.0 & 94.0 & 100.0 \\
\hline \multicolumn{5}{|c|}{ Cross-validated $^{6}$} \\
\hline \multirow[t]{2}{*}{ Count } & Spring & 48 & 12 & 60 \\
\hline & Summer & 8 & 75 & 83 \\
\hline \multirow[t]{2}{*}{$\%$} & Spring & 80.0 & 20.0 & 100.0 \\
\hline & Summer & 9.6 & 90.4 & 100.0 \\
\hline \multicolumn{5}{|c|}{ (C) Genitalia } \\
\hline \multicolumn{5}{|c|}{ Original } \\
\hline \multirow[t]{2}{*}{ Count } & Spring & 53 & 7 & 60 \\
\hline & Summer & 13 & 70 & 83 \\
\hline \multirow[t]{2}{*}{$\%$} & Spring & 88.3 & 11.7 & 100.0 \\
\hline & Summer & 15.7 & 84.3 & 100.0 \\
\hline \multicolumn{5}{|c|}{ Cross-validated $^{9}$} \\
\hline \multirow[t]{2}{*}{ Count } & Spring & 53 & 7 & 60 \\
\hline & Summer & 14 & 69 & 83 \\
\hline \multirow[t]{2}{*}{$\%$} & Spring & 88.3 & 11.7 & 100.0 \\
\hline & Summer & 16.9 & 83.1 & 100.0 \\
\hline
\end{tabular}

${ }^{1} 94.4 \%$ of original grouped cases correctly classified.

${ }^{2} 93.0 \%$ of cross-validated grouped cases correctly classified.

${ }^{3}$ Cross-validation is carried out only for those cases in the analysis. In cross-validation, each case is classified by the functions derived from all cases other than that case.

${ }^{4} 90.2 \%$ of original grouped cases correctly classified.

${ }^{5} 86.0 \%$ of cross-validated grouped cases correctly classified.

${ }^{6}$ Cross-validation is carried out only for those cases in the analysis. In cross-validation, each case is classified by the functions derived from all cases other than that case.

${ }^{7} 86.0 \%$ of original grouped cases correctly classified.

${ }^{8} 85.3 \%$ of cross-validated grouped cases correctly classified.

${ }^{9}$ Cross-validation is carried out only for those cases in the analysis. In cross-validation, each case is classified by the functions derived from all cases other than that case. 


\section{Author Query Form}

\section{Journal: $\quad$ JZS \\ Article: $\quad 12034$}

Dear Author,

During the copy-editing of your paper, the following queries arose. Please respond to these by marking up your proofs with the necessary changes/additions. Please write your answers on the query sheet if there is insufficient space on the page proofs. Please write clearly and follow the conventions shown on the attached corrections sheet. If returning the proof by fax do not write too close to the paper's edge. Please remember that illegible mark-ups may delay publication. Many thanks for your assistance.

\begin{tabular}{|c|c|c|}
\hline Query reference & Query & Remarks \\
\hline 1 & $\begin{array}{l}\text { AUTHOR: A running head short title was not supplied; please check if this one is } \\
\text { suitable and, if not, please supply a short title of up to } 40 \text { characters that can be } \\
\text { used instead. }\end{array}$ & \\
\hline 2 & $\begin{array}{l}\text { AUTHOR: Please check and confirm whether the edit made in the sentence "At } \\
\text { the same time, Sielezniew...phylogeny of Maculinea species" retain its intended } \\
\text { meaning. }\end{array}$ & \\
\hline 3 & $\begin{array}{l}\text { AUTHOR: According to style sheet requirement, first person narration is not } \\
\text { allowed. Kindly advise us whether to change or not in this article. }\end{array}$ & \\
\hline 4 & $\begin{array}{l}\text { AUTHOR: Please check whether the edits made in the sentence "Besides, we were } \\
\text { interested...in M. arion populations" retain its intended meaning. }\end{array}$ & \\
\hline 5 & AUTHOR: 14000 rpm: please replace this with the correct $g$ value. & \\
\hline 6 & AUTHOR: Please provide city name for Macrogen Inc. & \\
\hline 7 & $\begin{array}{l}\text { AUTHOR: Tamura et al. } 2007 \text { has not been included in the Reference List, please } \\
\text { supply full publication details. }\end{array}$ & \\
\hline 8 & $\begin{array}{l}\text { AUTHOR: Please check whether the edits made in the sentence "The MP search... } \\
\text { not in effect" retain its intended meaning. }\end{array}$ & \\
\hline 9 & $\begin{array}{l}\text { AUTHOR: Please give manufacturer information for TPSDIG v. 2.1: company name, } \\
\text { town, state (if USA), and country. }\end{array}$ & \\
\hline 10 & $\begin{array}{l}\text { AUTHOR: Journal style is to include all author names for each reference in the } \\
\text { reference list. Please replace all appearances of 'et al.' in your reference list with } \\
\text { the complete author lists. }\end{array}$ & \\
\hline 11 & $\begin{array}{l}\text { AUTHOR: Please provide last accessed date, month and year for reference Chesh- } \\
\text { ire (2011). }\end{array}$ & \\
\hline 12 & $\begin{array}{l}\text { AUTHOR: Please provide the publisher name for reference Munguira and Martin } \\
\text { (1997). }\end{array}$ & \\
\hline 13 & AUTHOR: Please provide the publisher location for reference Nylander (2004). & \\
\hline 14 & AUTHOR: Please provide the publisher location for reference Pajari (1992). & \\
\hline 15 & AUTHOR: Please provide the page range for reference Ronquist et al. (2012). & \\
\hline 16 & AUTHOR: Please provide the publisher location for reference Tartally (2008). & \\
\hline 17 & $\begin{array}{l}\text { AUTHOR: Please provide the publisher name, publisher location for reference } \\
\text { Van Swaay et al. (1998). }\end{array}$ & \\
\hline 18 & AUTHOR: Please check the publisher name for reference Verity $(1940-1953)$. & \\
\hline 19 & AUTHOR: Please check the usage of "?" here. & \\
\hline
\end{tabular}


AUTHOR: Figure 4 is of poor quality. Please check required artwork specifications at http://authorservices.wiley.com/bauthor/illustration.asp

21

AUTHOR: Figure 5 is of poor quality. Please check required artwork specifications at http://authorservices.wiley.com/bauthor/illustration.asp 
Required software to e-Annotate PDFs: Adobe Acrobat Professional or Adobe Reader (version 7.0 or above). (Note that this document uses screenshots from Adobe Reader $\mathbf{X}$ )

The latest version of Acrobat Reader can be downloaded for free at: http://get.adobe.com/uk/readerl

Once you have Acrobat Reader open on your computer, click on the Comment tab at the right of the toolbar:

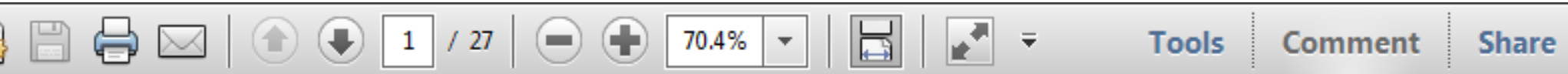

This will open up a panel down the right side of the document. The majority of tools you will use for annotating your proof will be in the Annotations section, pictured opposite. We've picked out some of these tools below:

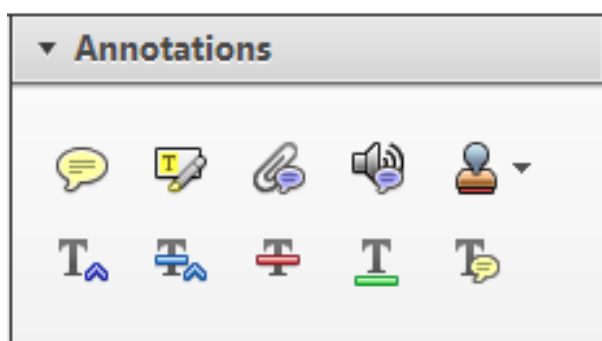

1. Replace (Ins) Tool - for replacing text.

Strikes a line through text and opens up a text box where replacement text can be entered.

How to use it

- Highlight a word or sentence

- Click on the Replace (Ins) icon in the Annotations section.

- Type the replacement text into the blue box that appears.

Idard tramework for the analysis of $\mathrm{m}$ icy-Nevertheless, it also led to exog،

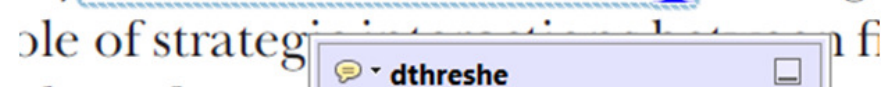
aber of comp 08/06/2011 15:58:17 is that the $\mathrm{s} 1 \overline{\text {, which led }}$ of nain compo: be level, are exc nc

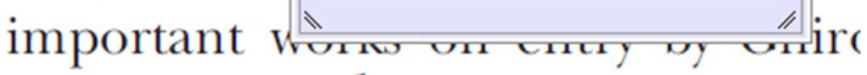
M henceforth) ${ }^{1}$ we snen the "hlark $\mathrm{h}$

3. Add note to text Tool - for highlighting a section to be changed to bold or italic.

Th Highlights text in yellow and opens up a text box where comments can be entered.

\section{How to use it}

- Highlight the relevant section of text.

- Click on the Add note to text icon in the Annotations section.

- Type instruction on what should be changed regarding the text into the yellow box that appears

namic responses of mark ups ent with the VAR evidence

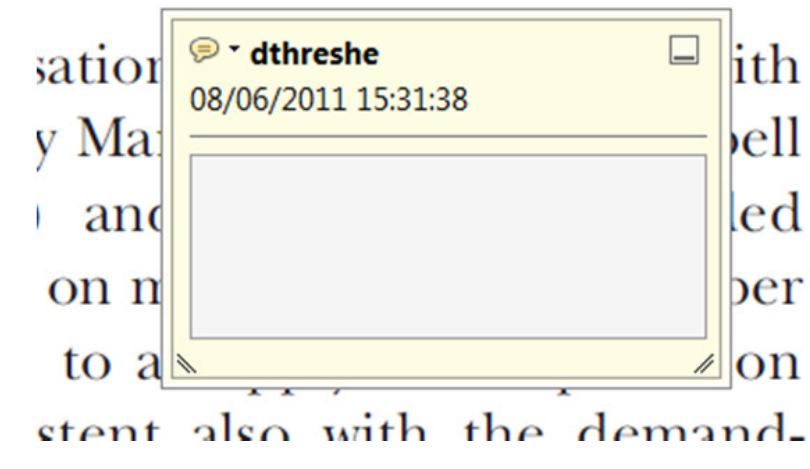

2. Strikethrough (Del) Tool - for deleting text.

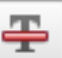

Strikes a red line through text that is to be deleted.

How to use it

- Highlight a word or sentence.

- Click on the Strikethrough (Del) icon in the Annotations section.

there is no room tor extra prohts al s ups are zero and the number of ret) values are not determined by Blanchard and Kiyotaki (1987), sfect competition in general equilil ts of aggregate demand and supply lassical framework assuming mono sen on evorenous nimher of firms

4. Add sticky note Tool - for making notes at specific points in the text.

Marks a point in the proof where a comment needs to be highlighted.

How to use it

- Click on the Add sticky note icon in the Annotations section.

- Click at the point in the proof where the comment should be inserted.

- Type the comment into the yellow box that appears.

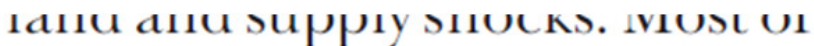

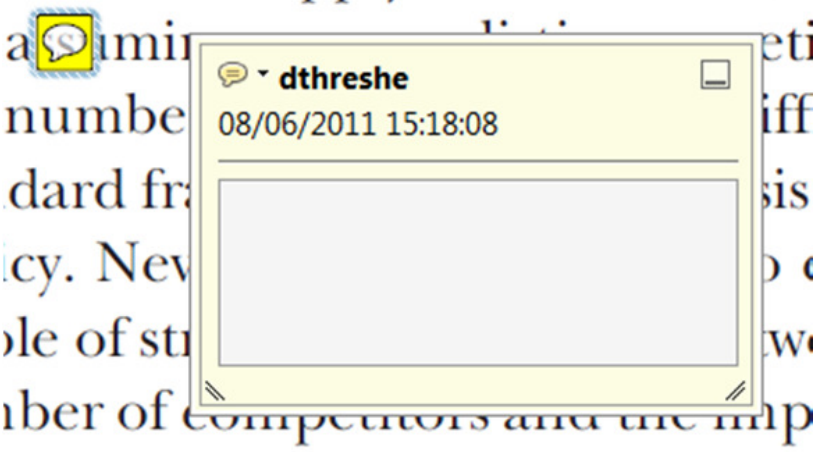

is that the structure of the sects. 
5. Attach File Tool - for inserting large amounts of text or replacement figures.

Inserts an icon linking to the attached file in the appropriate pace in the text.

How to use it

- Click on the Attach File icon in the Annotations section.

- Click on the proof to where you'd like the attached file to be linked.

- Select the file to be attached from your computer or network.

- Select the colour and type of icon that will appear in the proof. Click OK.

E N D

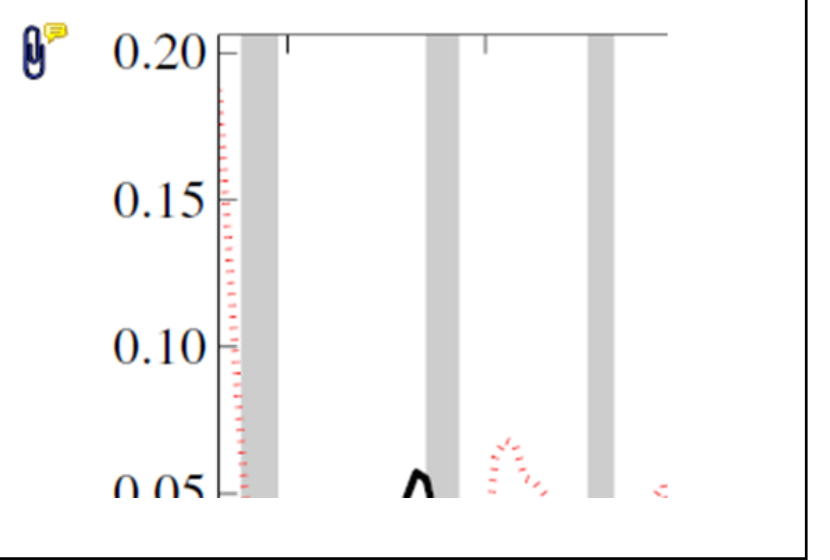

6. Add stamp Tool - for approving a proof if no corrections are required.

- Inserts a selected stamp onto an appropriate place in the proof

\section{How to use it}

- Click on the Add stamp icon in the Annotations section.

- Select the stamp you want to use. (The Approved stamp is usually available directly in the menu that appears).

- Click on the proof where you'd like the stamp to appear. (Where a proof is to be approved as it is, this would normally be on the first page).

of the Dusiness cycie, starting with the on perfect competition, constant ret

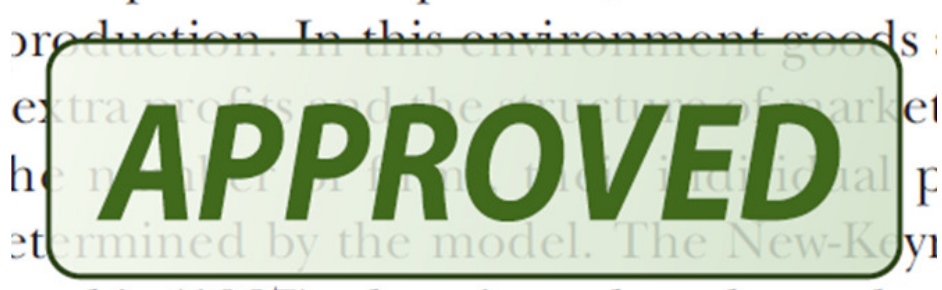
otaki (1987), has introduced produc general equilibrium models with nomin:

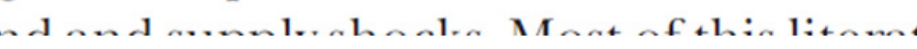

- Drawing Markups

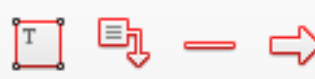

$0 \square \sqrt{ } \rightarrow 0$

\section{How to use it}

- Click on one of the shapes in the Drawing Markups section.

- Click on the proof at the relevant point and draw the selected shape with the cursor.

- To add a comment to the drawn shape, move the cursor over the shape until an arrowhead appears.

- Double click on the shape and type any text in the red box that appears.
7. Drawing Markups Tools - for drawing shapes, lines and freeform annotations on proofs and commenting on these marks.

Allows shapes, lines and freeform annotations to be drawn on proofs and for comment to be made on these marks.

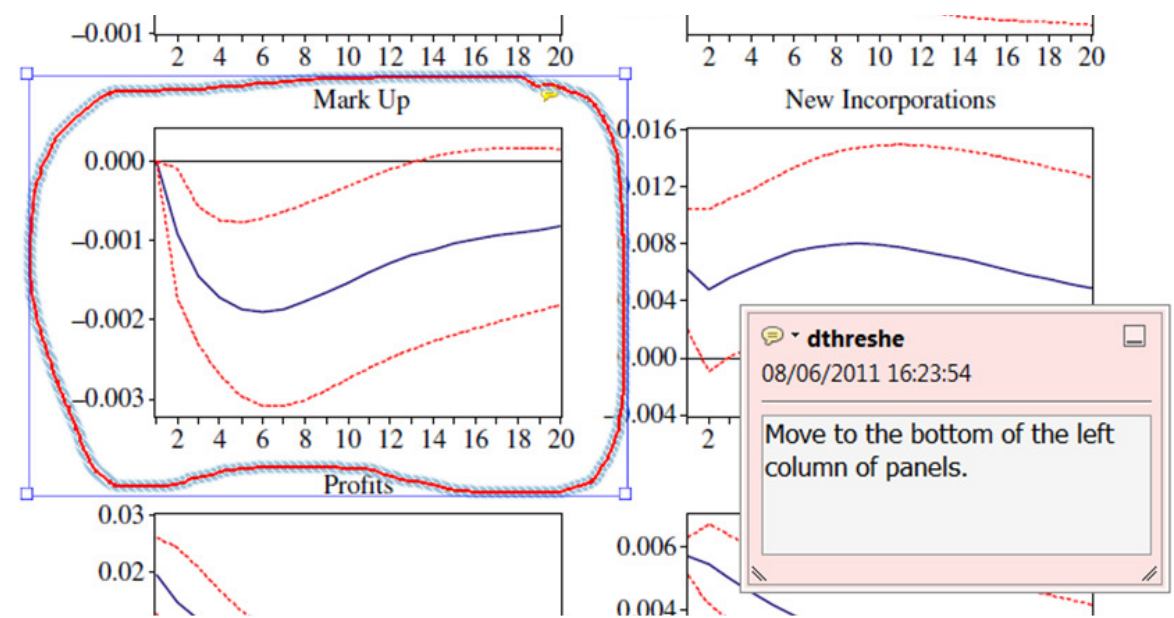

For further information on how to annotate proofs, click on the Help menu to reveal a list of further options:

\begin{tabular}{|l|l|l|l|l|l|l|}
\hline File ecoj_2384_CrxRev2_EV_19-Jul-10.pdf - Adobe Reader & Edit View Window \\
\hline
\end{tabular}

